\title{
Phytohemagglutinin improves the development and ultrastructure of in vitro-cultured goat (Capra hircus) preantral follicles
}

\author{
E.V. Cunha ${ }^{1}$, J.J.N. Costa ${ }^{1}$, R.O.D.S. Rossi ${ }^{1}$, A.W.B. Silva ${ }^{1}$, J.R.S. Passos ${ }^{1}$, A.M.L.R. Portela ${ }^{1}$, \\ D.C.S.T. Pereira ${ }^{1}$, M.A.M. Donato ${ }^{3}$, C.C. Campello ${ }^{2}$, M.V.A. Saraiva ${ }^{1}$, C.A. Peixoto ${ }^{3}$, \\ J.R.V. Silva ${ }^{1}$ and R.P. Santos ${ }^{1}$ \\ ${ }^{1}$ Núcleo de Biotecnologia de Sobral, NUBIS, Universidade Federal do Ceará, Sobral, CE, Brasil \\ ${ }^{2}$ Laboratório de Manipulação de Oócitos e Folículos Pré-Antrais, Faculdade de Medicina Veterinária, Universidade Estadual do Ceará, \\ Fortaleza, CE, Brasil \\ ${ }^{3}$ Laboratório de Ultraestrutura, CPqAM/FIOCRUZ, Universidade Federal de Pernambuco, Recife, PE, Brasil
}

\begin{abstract}
The objective this study was to determine the effect of phytohemagglutinin (PHA) on survival, growth and gene expression in caprine secondary follicles cultured in vitro. Secondary follicles $(\sim 0.2 \mathrm{~mm})$ were isolated from the cortex of caprine ovaries and cultured individually for 6 days in $\alpha-\mathrm{MEM}^{+}$supplemented with PHA $(0,1,10,50,100$, or $200 \mu \mathrm{g} / \mathrm{mL})$. After 6 days of culture, follicle diameter and survival, antrum formation, ultrastructure and expression of mRNA for FSH receptors (FSH-R), proliferating cell nuclear antigen (PCNA), and neuronal nitric oxide synthase were determined. All treatments maintained follicular survival $\left[\alpha-\mathrm{MEM}^{+}\right.$(94.59\%); $1 \mu \mathrm{g} / \mathrm{mL}$ PHA (96.43\%); $10 \mu \mathrm{g} / \mathrm{mL}$ PHA (84.85\%); $50 \mu \mathrm{g} / \mathrm{mL}$ PHA (85.29\%); $100 \mu \mathrm{g} / \mathrm{mL}$ PHA (88.57\%), and $200 \mu \mathrm{g} / \mathrm{mL}$ PHA (87.50)], but the presence of $10 \mu \mathrm{g} / \mathrm{mL}$ PHA in the culture medium increased the antrum formation rate $(21.21 \%)$ when compared with control $(5.41 \%, P<0.05)$ and ensured the maintenance of oocyte and granulosa cell ultrastructures after 6 days of culture. The expression of mRNA for FSH-R $(2.7 \pm 0.1)$ and PCNA (4.4 \pm 0.2$)$ was also significantly increased in follicles cultured with $10 \mu \mathrm{g} / \mathrm{mL}$ PHA in relation to those cultured in $\alpha-\mathrm{MEM}^{+}(1.0 \pm 0.1)$. In conclusion, supplementation of culture medium with $10 \mu \mathrm{g} / \mathrm{mL}$ PHA maintains the follicular viability and ultrastructure, and promotes the formation of antral cavity after 6 days of culture in vitro.
\end{abstract}

Key words: Caprine; Antrum formation; FSH-R; PCNA; Ultrastructure

\section{Introduction}

The development of efficient culture systems is extremely important both to understand the mechanisms that regulate follicular development and to assure the in vitro follicular growth up to the stage at which the oocytes are capable of being matured and fertilized in vitro. In different species, great advances have been made in culturing preantral follicles. In human, bovine and canine species, secondary follicles have grown in vitro until the stage of antral follicles (1-3). More satisfactory results were obtained in porcine (4), bubaline (5), ovine (6), and caprine (7) species, since a small number of embryos have been obtained after fertilization of oocytes from in vitro-grown secondary follicles. To improve this technique in domestic species it is necessary to study substances that may contribute to promote the oocyte growth and proliferation of granulosa cells. Several hormones and growth factors, such as follicle-stimulating hormone (FSH) $(8,9)$, growth and differentiation factor-9 (10) and kit ligand (11), have been tested during the culture of caprine preantral follicles. Among them, $\mathrm{FSH}$ is the main regulator of ovarian function and its receptor has been demonstrated in goat preantral follicles (7). However, the effects of substances not produced by the ovaries, such as lectins, have not been described.

Lectins have been isolated from various sources and have a wide spectrum of biological activities (12). Most of them are proteins or glycoproteins that specifically bind to carbohydrates. In addition to recognizing sugars, some lectins promote mitogenic stimulation of lymphocytes (13), leukocytes (14) and fibroblasts (15). Phytohemagglutinin 
$(\mathrm{PHA})$ is a lectin extracted from Phaseolus vulgaris, which bind to complex oligosaccharide containing $\mathrm{N}$-acetylgalactosamine/galactose residues (15). Due to its ability to stimulate subpopulations of T cells, the PHA has been used as a mitogen to increase proliferation of various cell types in vitro (16). Fagbohun and Downs (17) demonstrated that mitogenic lectins, such as $\mathrm{PHA}$, promote oocyte maturation and cumulus cell expansion in rats. On the other hand, Wang et al. (18) showed that the PHA has no apparent effect during maturation of bovine oocytes. Furthermore, PHA has been used to improve the efficiency of the nuclear transfer of somatic cells for oocytes from diverse species (19), because its capacity to induce closer contacts between adjacent cell membranes. In addition, PHA can stimulate the production of nitric oxide (NO) in different cells $(20,21)$. Some studies have shown that neuronal NO synthase (nNOS) is expressed in ovarian follicles (22) and is involved in the control of folliculogenesis, steroidogenesis, oocyte maturation, and ovulation through the production of NO (23).

The aim of this study was to evaluate the effect of different concentrations of PHA on survival, growth, antrum formation, and ultrastructure of caprine secondary follicles cultured in vitro. In addition, the effect of PHA on the expression of mRNA for proliferating cell nuclear antigen (PCNA), FSH, FSH receptors (FSH-R), and nNOS was analyzed.

\section{Material and Methods}

\section{Chemicals}

Unless otherwise stated, the culture media, the lectin PHA (Cat. No. L-1668) and other chemicals were purchased from Sigma-Aldrich Corp. (USA). The stock solution of the lectin PHA was prepared in phosphatebuffered saline, $\mathrm{pH} 7.2$, and stored at $-20^{\circ} \mathrm{C}$.

\section{Source of ovaries}

Ovaries ( $n=42)$ from 21 adult ( 1 to 3 years old) crossbreed goats (Capra hircus) were collected at a local slaughterhouse. Immediately postmortem, the surrounding fat tissue and ligaments were removed and the ovaries were washed in $70 \%$ alcohol followed by two washes in sterile saline solution. The ovaries were placed into tubes containing $20 \mathrm{~mL}$ alpha minimum essential medium ( $\alpha$-MEM), supplemented with $200 \mathrm{IU} / \mathrm{mL}$ penicillin and $150 \mu \mathrm{g} / \mathrm{mL}$ streptomycin and then transported to the laboratory at $4^{\circ} \mathrm{C}$ within $1 \mathrm{~h}$.

\section{Isolation and in vitro culture of preantral follicles}

Ovarian cortical slices $(1 \mathrm{~mm})$ were cut from the ovarian surface, using a surgical blade under sterile conditions. The slices were subsequently placed in fragmentation medium, consisting of $\alpha$-MEM supplemented with $150 \mathrm{IU} / \mathrm{mL}$ penicillin and $150 \mu \mathrm{g} / \mathrm{mL}$ streptomycin. Secondary follicles $(\sim 0.2 \mathrm{~mm})$ were visualized under a stereomicroscope (SMZ 645 Nikon, Japan) and manually dissected from strips of ovarian cortex using 26 gauge (26 $\mathrm{G})$ needles. Follicles with a visible oocyte, surrounded by two or more granulosa cell layers, an intact basement membrane and no antral cavity were selected for culture. After selection, follicles were cultured individually in $100 \mu \mathrm{L}$ drops of culture medium under mineral oil on Petri dishes $(60 \times 15 \mathrm{~mm}$, Corning, USA). The basic culture medium ( $\alpha$ $\mathrm{MEM}^{+}$) consisted of $\alpha-\mathrm{MEM}, \mathrm{pH} 7.2-7.4$, supplemented with $3.0 \mathrm{mg} / \mathrm{mL}$ bovine serum albumin, $1 \%$ ITS $(10 \mu \mathrm{g} / \mathrm{mL}$ insulin, $5.5 \mu \mathrm{g} / \mathrm{mL}$ transferrin, and $5 \mathrm{ng} / \mathrm{mL}$ selenium), $2 \mathrm{mM}$ glutamine, $2 \mathrm{mM}$ hypoxanthine, $50 \mu \mathrm{g} / \mathrm{mL}$ ascorbic acid, $150 \mathrm{IU} / \mathrm{mL}$ penicillin, $150 \mathrm{IU} / \mathrm{mL}$ streptomycin, and $100 \mathrm{ng} / \mathrm{mL} \mathrm{FSH}$ (from sheep pituitary, Sigma). Follicles were randomly distributed in each of the following treatments: $\alpha-\mathrm{MEM}^{+}$alone (control) and $\alpha-\mathrm{MEM}^{+}$associated with lectin PHA at concentrations of $1,10,50,100$, or $200 \mu \mathrm{g} / \mathrm{mL}$. Incubation was carried out at $39^{\circ} \mathrm{C}$ and $5 \% \mathrm{CO}_{2}$ in air for 6 days. Previous studies have shown that goat preantral follicles begin their growth from $24 \mathrm{~h}$ of in vitro culture and antrum formation occurs after 6 days (24). Fresh media were prepared before use and incubated for $2 \mathrm{~h}$ prior to use. Every other day, $60 \mu \mathrm{L}$ of the culture media was replaced with fresh medium. The culture was replicated four times, and at least 28 follicles were cultured per treatment.

\section{Morphological evaluation of follicular development}

After 6 days of culture, follicles were classified according to their morphology. A follicle was considered to be normal when presented a centrally located spherical and homogeneous oocyte, surrounded by compact layers of granulosa cells, and without apparent damage to the basement membrane in the beginning of culture. Those follicles that showed morphological signs of degeneration, such as darkness of oocytes and surrounding granulosa cells or those with misshapen oocytes, were considered to be degenerated. The follicular growth, survival and the presence/absence of the antral cavity were evaluated every 2 days of culture. Antral cavity formation was defined as a visible translucent cavity within the granulosa cell mass. Follicular diameter was measured only in healthy follicles by calculating two perpendicular diameters using Motic Images Plus 2.0. In order to better examine follicular morphology, transmission electron microscopy was performed to analyze the ultrastructure of caprine secondary follicles grown in control medium and in the treatment that provided the best.

\section{Ultrastructural analysis of follicles cultured in vitro}

Transmission electron microscopy was used to analyze the ultrastructure of preantral follicles cultured with $\alpha$ $\mathrm{MEM}^{+}$alone or supplemented with $10 \mu \mathrm{g} / \mathrm{mL}$ PHA. Cultured follicles were fixed in Karnovsky solution (4\% paraformaldehyde and $2.5 \%$ glutaraldehyde in $0.1 \mathrm{M}$ sodium cacodylate buffer, $\mathrm{pH} 7.2$ ) for at least $4 \mathrm{~h}$ at room temperature (approximately $25^{\circ} \mathrm{C}$ ). After fixation, follicles 
were embedded in drops of $4 \%$ low melting agarose, and kept in sodium cacodylate buffer. Specimens were postfixed in $1 \%$ osmium tetroxide, $0.8 \%$ potassium ferricyanide and $5 \mathrm{mM}$ calcium chloride in $0.1 \mathrm{M}$ sodium cacodylate buffer for $1 \mathrm{~h}$ at room temperature, washed in sodium cacodylate buffer and counterstained with $5 \%$ uranyl acetate. The samples were then dehydrated through a gradient of acetone solutions and thereafter embedded in epoxy resin (Epoxy-Embedding Kit, Fluka Chemika-BioChemika, Switzerland). Afterwards, semithin sections $(2 \mu \mathrm{m})$ were cut, stained with toluidine blue and analyzed by light microscopy at a 400X magnification. Ultra-thin sections $(70 \mathrm{~nm})$ were obtained from caprine preantral follicles classified as morphologically normal in semi-thin sections. Subsequently, ultra-thin sections were counterstained with uranyl acetate and lead citrate, and examined under a Morgani-FEl transmission electron microscope (FEl, The Netherlands).

\section{Expression of mRNA for FSH-R, PCNA and nNOS in cultured follicles}

To evaluate RNA expression, three groups of 8 follicles, from three different replicates, cultured either in control medium or in medium supplemented with $10 \mu \mathrm{g} /$ $\mathrm{mL}$ PHA were collected and stored in microcentrifuge tubes at $-80^{\circ} \mathrm{C}$.

Total RNA was extracted using the TRIzol ${ }^{\circledR}$ reagent (Invitrogen, Brazil). According to manufacturer instructions, $1 \mathrm{~mL}$ Trizol solution was added to each frozen samples and the lysate was aspirated through a 20-gauge needle before centrifugation at $10,000 \mathrm{~g}$ for $3 \mathrm{~min}$ at room temperature. Thereafter, all lysates were diluted 1:1 with $70 \%$ ethanol and subjected to a mini-column. After binding of the RNA to the column, DNA digestion was performed using RNAse-free DNAse (340 Kunitz U/mL) for $15 \mathrm{~min}$ at room temperature. After washing the column three times, the RNA was eluted with $30 \mu \mathrm{L}$ RNAse-free water. The RNA concentration was estimated by reading the absorbance at $260 \mathrm{~nm}$ and was checked for purity at $280 \mathrm{~nm}$ in a spectrophotometer (Amersham Biosciences, England). Before the reverse transcription reaction, samples of RNA were incubated for $5 \mathrm{~min}$ at $70^{\circ} \mathrm{C}$ and then cooled in ice. From $2 \mu \mathrm{g}$ of total RNA, the reverse transcription was performed in a total volume of $20 \mu \mathrm{L}$ composed of $10 \mu \mathrm{L}$ sample RNA, $4 \mu \mathrm{L}$ reverse transcriptase buffer (Invitrogen), $8 \cup$ RNAsin, $150 \cup$ reverse transcriptase Superscript III, $0.036 \mathrm{U}$ random primers, $10 \mathrm{mM}$ DTT and $0.5 \mathrm{mM}$ of each dNTP (Invitrogen). The mixture was incubated at $42^{\circ} \mathrm{C}$ for $1 \mathrm{~h}$, subsequently at $80^{\circ} \mathrm{C}$ for $5 \mathrm{~min}$, and finally stored at $-20^{\circ} \mathrm{C}$. The negative control was prepared under the same conditions, but without addition of reverse transcriptase.

Quantification of the mRNA for FSH-R, PCNA, and nNOS was performed by using SYBR Green. Each reaction in real-time $(20 \mu \mathrm{L})$ containing $10 \mu \mathrm{L}$ SYBR Green Master Mix (Applied Biosystems, UK), 7.3 $\mu \mathrm{L}$ ultrapure water, $1 \mu \mathrm{L}$ cDNA and $5 \mu \mathrm{M}$ of each primer. Real-time PCR was performed in a thermocycler (Mastercycler ${ }^{\circledR}$ ep Realplex, Eppendorf, Germany). The primers designed to perform amplification of mRNA for FSH-R, PCNA and nNOS are shown in Table 1. This Table also shows the primers for $\beta$-actin and phosphoglycerate kinase, which were used as endogenous controls for normalization of gene expression. The specificity of each primer pair was confirmed by melting curve analysis of PCR products. The thermal cycling profile for the first round of PCR was: initial denaturation and activation of the polymerase for $10 \mathrm{~min}$ at $95^{\circ} \mathrm{C}$, followed by 50 cycles of $15 \mathrm{~s}$ at $95^{\circ} \mathrm{C}, 30 \mathrm{~s}$ at $58^{\circ} \mathrm{C}$, and $30 \mathrm{~s}$ at $72^{\circ} \mathrm{C}$. The final extension was for $10 \mathrm{~min}$ at $72^{\circ} \mathrm{C}$. The delta-delta-CT method was used to transform CT values into normalized relative expression levels (25).

Table 1. Primer pairs used in real-time PCR for quantification of FSH-R, PCNA and $n N O S$ in cultured caprine follicles with $10 \mu \mathrm{g} / \mathrm{mL}$ phytohemagglutinin.

\begin{tabular}{|c|c|c|c|}
\hline Target gene & Sequence $\left(5^{\prime} \rightarrow 3^{\prime}\right)$ & Position & GenBank No. \\
\hline \multirow[t]{2}{*}{$\beta$-actin } & S: ACCACTGGCATTGTCATGGACTCT & $188-211$ & GI: 28628620 \\
\hline & AS: TCCTTGATGTCACGGACGATTTCC & $363-386$ & \\
\hline \multirow[t]{2}{*}{ PGK } & S: AGCCTTCCGAGCTTCACTTT & $444-466$ & GI: 77735550 \\
\hline & AS: AAACCTCCAGCCTTCTTTGGCA & $541-563$ & \\
\hline \multirow[t]{2}{*}{ FSH-R } & S: AGGCAAATGTGTTCTCCAACCTGC & $250-274$ & GI: 95768228 \\
\hline & AS: TGGAAGGCATCAGGGTCGATGTAT & $316-340$ & \\
\hline \multirow[t]{2}{*}{ PCNA } & S: TGCCGAGATCTCAGTCACAT & $566-586$ & GI: 77735938 \\
\hline & AS: TATGGCAACAGCTTCCTCCT & $695-715$ & \\
\hline \multirow[t]{2}{*}{ nNOS } & S: TGGAGGATGTGGCCAAGAAGATGA & $1835-1859$ & GI: 358416368 \\
\hline & AS: TCTGGAAGCTGTACAGAACCGCAA & $1942-1966$ & \\
\hline
\end{tabular}

$\mathrm{S}=$ sense; $\mathrm{AS}=$ antisense; $\mathrm{PGK}=$ phosphoglycerate kinase; $\mathrm{FSH}-\mathrm{R}=$ follicle-stimulating hormone receptors; PCNA = proliferating cell nuclear antigen; nNOS $=$ neuronal nitric oxide synthase. 
Table 2. Follicular diameters of caprine secondary follicles cultured for 6 days in $\alpha$-MEM ${ }^{+}$supplemented with different concentrations of PHA.

\begin{tabular}{lcccccc}
\hline $\begin{array}{l}\text { Period } \\
\text { (days) }\end{array}$ & $\alpha-\mathrm{MEM}^{+}$ & $\begin{array}{c}\mathrm{PHA} \\
(1 \mu \mathrm{g} / \mathrm{mL})\end{array}$ & $\begin{array}{c}\text { PHA } \\
(10 \mu \mathrm{g} / \mathrm{mL})\end{array}$ & $\begin{array}{c}\text { PHA } \\
(50 \mu \mathrm{g} / \mathrm{mL})\end{array}$ & $\begin{array}{c}\text { PHA } \\
(100 \mu \mathrm{g} / \mathrm{mL})\end{array}$ \\
\hline 0 & $181.30 \pm 41.70^{\mathrm{b}}$ & $179.78 \pm 47.66^{\mathrm{b}}$ & $173.98 \pm 46.91^{\mathrm{b}}$ & $160.00 \pm 49.39^{\mathrm{b}}$ & $181.49 \pm 56.38^{\mathrm{b}}$ & $173.08 \pm 48.15^{\mathrm{b}}$ \\
2 & $199.98 \pm 50.83^{\mathrm{ab}}$ & $197.67 \pm 56.10^{\mathrm{a}}$ & $201.04 \pm 58.11^{\mathrm{ab}}$ & $186.49 \pm 58.81^{\mathrm{ab}}$ & $216.24 \pm 69.20^{\mathrm{a}}$ & $206.50 \pm 66.24^{\mathrm{a}}$ \\
4 & $214.29 \pm 59.30^{\mathrm{a}}$ & $205.64 \pm 64.10^{\mathrm{a}}$ & $215.88 \pm 66.40^{\mathrm{a}}$ & $194.30 \pm 57.34^{\mathrm{ab}}$ & $228.08 \pm 69.76^{\mathrm{a}}$ & $217.07 \pm 62.14^{\mathrm{a}}$ \\
6 & $225.96 \pm 65.26^{\mathrm{a}}$ & $212.30 \pm 60.01^{\mathrm{a}}$ & $228.34 \pm 76.50^{\mathrm{a}}$ & $200.90 \pm 54.27^{\mathrm{a}}$ & $230.76 \pm 70.92^{\mathrm{a}}$ & $223.51 \pm 64.25^{\mathrm{a}}$ \\
\hline
\end{tabular}

Data are reported as means $\pm \mathrm{SD} . \alpha-\mathrm{MEM}^{+}=$alpha minimum essential medium; PHA $=$phytohemagglutinin. Different superscript letters indicate statistically significant differences within a column $(\mathrm{P}<0.05$, paired $t$-test).

\section{Statistical analyses}

The percent of follicular survival and antrum formation after in vitro culture were compared by the Fisher exact test and the results are reported as percent. The data corresponding to the follicular diameter were subjected to the Shapiro-Wilk test and the Bartlett test for verification of normal distribution and homoscedasticity, respectively. Follicular diameters show homogeneity of variance and were compared by the paired $t$-test. The results are reported as means $\pm S D$ and differences were considered to be significant when $\mathrm{P}<0.05$. The levels of mRNA for FSH-R, PCNA, and nNOS in follicles cultured in the treatments were examined by the Mann-Whitney U-test. The results are reported as means \pm SE and differences were considered to be significant when $\mathrm{P}<0.05$.

\section{Results}

\section{Effect of PHA on survival and growth of goat secondary follicles}

At the end of the period of culture, all treatments were capable of maintaining follicular survival and no significant difference $(P>0.05)$ among them were observed $[\alpha-$ $\mathrm{MEM}^{+}(94.59 \%) ; 1 \mu \mathrm{g} / \mathrm{mL} \mathrm{PHA}(96.43 \%) ; 10 \mu \mathrm{g} / \mathrm{mL} \mathrm{PHA}$ (84.85\%); $50 \mu \mathrm{g} / \mathrm{mL}$ PHA (85.29\%); $100 \mu \mathrm{g} / \mathrm{mL}$ PHA (88.57\%), and $200 \mu \mathrm{g} / \mathrm{mL}$ PHA (87.50\%)]. Regarding the follicular diameter, from day 0 to 6 of culture, a significant increase in follicular diameter was observed in all treatments $(P<0.05)$, but no differences were found among them (Table 2).
Regarding the antrum formation, at the end of culture, follicles cultured in the presence of $10 \mu \mathrm{g} / \mathrm{mL} P H A$ showed a significant increase in antrum formation when compared to the control medium $\left(\alpha-\mathrm{MEM}^{+}\right)$. On the other hand, the percent of antrum formation in follicles cultured with $1,50,100$, and $200 \mu \mathrm{g} / \mathrm{mL}$ PHA did not differ either from the control treatment or among each other (Table 3 ).

\section{Ultrastructural analysis of follicles cultured in vitro}

The ultrastructural analysis showed that follicles cultured in $\alpha-\mathrm{MEM}^{+}$had an abnormal profile, the oocyte cytoplasm was extremely vacuolated, having a greater open area and organelles were no longer recognizable in ooplasm (Figure 1A). Despite a regular zona pellucida and well-organized granulosa cells surrounding the oocyte, these follicles had reduced number of microvilli (Figure 1A). On the other hand, follicles cultured in medium supplemented with $10 \mu \mathrm{g} / \mathrm{mL}$ PHA (Figure 1B and $C$ ) presented a well-preserved oocyte, with visible organelles, such as Golgi complex, endoplasmic reticulum and lipid droplets. Mitochondria had some swollenness, but this feature is common in cultured cells. Granulosa cells were present with normal organelles and regular chromatin. Zona pellucida was preserved, and microvilli were evident.

\section{Levels of mRNA for FSH-R, PCNA and nNOS in cultured follicles}

Levels of mRNA for FSH-R, PCNA and nNOS in follicles cultured in $\alpha-\mathrm{MEM}^{+}$alone or supplemented with

Table 3. Percentages of follicles showing signs of antrum formation after culture of secondary follicles in $\alpha-\mathrm{MEM}^{+}$supplemented with different concentrations of PHA.

\begin{tabular}{lclclll}
\hline $\begin{array}{l}\text { Period } \\
\text { (days) }\end{array}$ & $\alpha-\mathrm{MEM}^{+}$ & $\mathrm{PHA}(1 \mu \mathrm{g} / \mathrm{mL})$ & $\mathrm{PHA}(10 \mu \mathrm{g} / \mathrm{mL})$ & $\mathrm{PHA}(50 \mu \mathrm{g} / \mathrm{mL})$ & $\mathrm{PHA}(100 \mu \mathrm{g} / \mathrm{mL})$ & $\mathrm{PHA}(200 \mu \mathrm{g} / \mathrm{mL})$ \\
\hline 0 & $0.00 \%(00 / 37)$ & $0.00 \%(00 / 28)$ & $0.00 \%(00 / 33)$ & $0.00 \%(00 / 34)$ & $0.00 \%(00 / 35)$ & $0.00 \%(00 / 00)$ \\
2 & $0.00 \%(00 / 37)$ & $0.00 \%(00 / 28)$ & $6.06 \%(02 / 33)$ & $0.00 \%(00 / 34)$ & $0.00 \%(00 / 35)$ & $0.00 \%(00 / 00)$ \\
4 & $0.00 \%(00 / 37)$ & $3.57 \%(01 / 28)^{\mathrm{A}}$ & $12.12 \%(04 / 33)^{\mathrm{A}}$ & $0.00 \%(00 / 34)$ & $5.71 \%(02 / 35)^{\mathrm{A}}$ & $0.00 \%(00 / 00)$ \\
6 & $5.41 \%(02 / 37)^{\mathrm{B}}$ & $7.14 \%(02 / 28)^{\mathrm{AB}}$ & $21.21 \%(07 / 33)^{\mathrm{A}}$ & $5.88 \%(02 / 34)^{\mathrm{AB}}$ & $5.71 \%(02 / 35)^{\mathrm{AB}}$ & $0.00 \%(00 / 00)$ \\
\hline
\end{tabular}

Data are reported as percent with number of antrum formations in parentheses. $\alpha-\mathrm{MEM}^{+}=$alpha minimum essential medium; $\mathrm{PHA}=$ phytohemagglutinin. Different superscript letters indicate statistically significant differences within a row $(P<0.05$, Fisher exact test). 

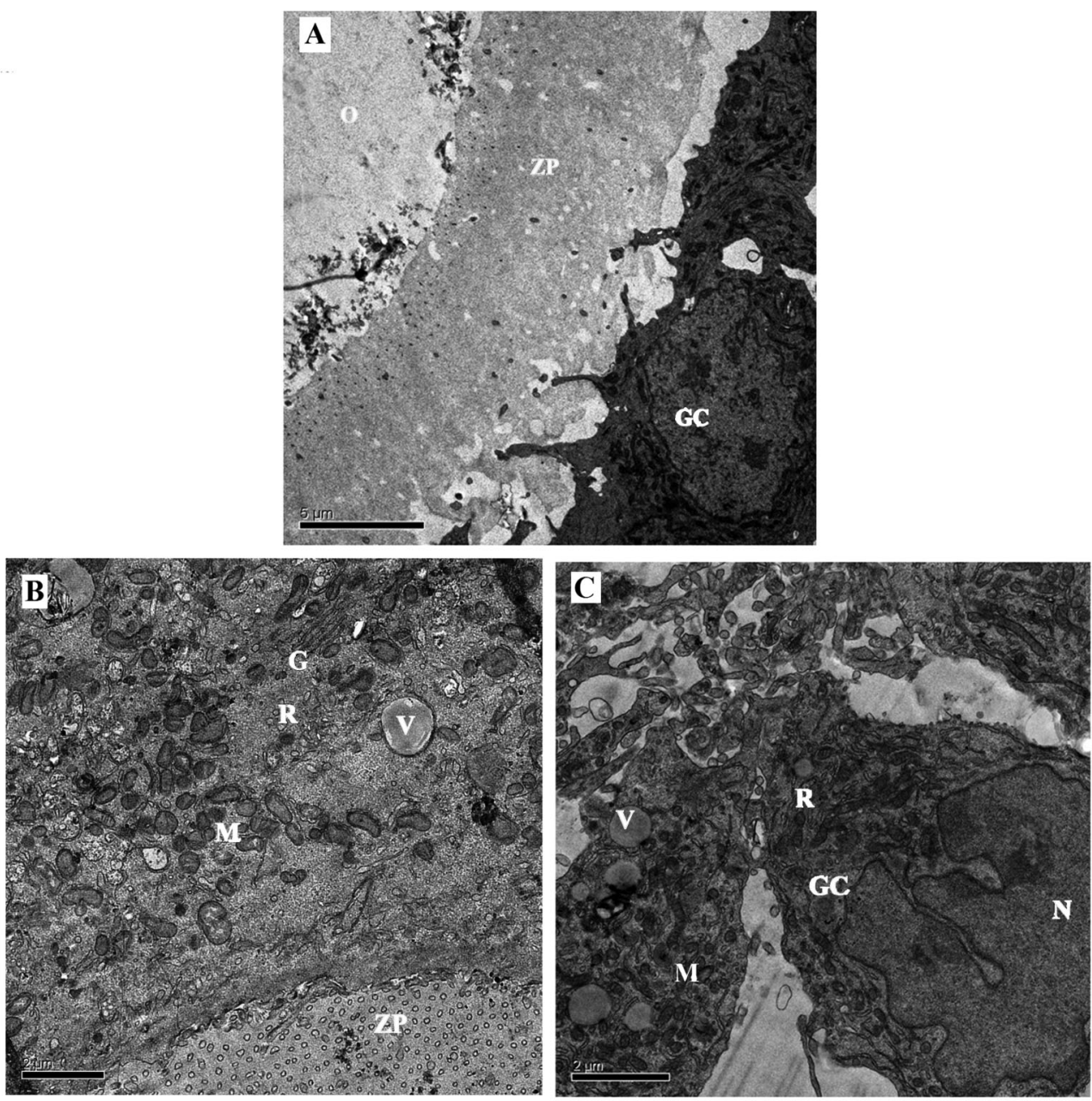

Figure 1. Transmission electron microscopy micrographs of $(A)$ follicle cultured in $\alpha-\mathrm{MEM}^{+}$showing abnormal ultrastructure, with no visible organelles and ooplasm; zona pellucida was present, with a paucity of microvilli. Panels $B$ and $C$ show follicles cultured with $10 \mu \mathrm{g} /$ $\mathrm{mL}$ PHA with normal mitochondria, Golgi complex, endoplasmic reticulum, and zona pellucida. $\mathrm{O}=$ oocyte; $\mathrm{N}=$ nucleus; $\mathrm{M}=$ mitochondria; $\mathrm{R}=$ endoplasmic reticulum; $\mathrm{ZP}=$ zona pellucida; $\mathrm{V}=$ vesicles; $\mathrm{GC}=$ granulosa cells. Bars: $A=5 \mu \mathrm{m} ; B$ and $C=2 \mu \mathrm{m}$.

$10 \mu \mathrm{g} / \mathrm{mL}$ PHA are shown in Figure 2. No significant difference in the levels of mRNA for nNOS between follicles cultured in control medium or medium supplemented with PHA was observed. However, the presence of PHA significantly increased the levels of mRNA for both PCNA and FSH-R, when compared with the control medium (Figure 2).

\section{Discussion}

The present study demonstrated that PHA $(10 \mu \mathrm{g} / \mathrm{mL})$ stimulates antrum formation, helps to keep ultrastructure integrity and increases the expression of $\mathrm{FSH}-\mathrm{R}$ and PCNA in caprine preantral follicles cultured in vitro.

Morphological analysis showed that after 6 days of culture, high survival rates were observed in all the treatments. This is probably due to the use of a culture medium rich of nutrients such as vitamins, amino acids and minerals that have been successfully used to culture preantral follicles (26). FSH is known to support follicle viability by inhibiting the expression of anti-apoptotic proteins (27) and its presence in the culture medium certainly helped to maintain follicles viable. Other studies have shown that FSH is very important for preantral follicle survival in different species $(2,28)$. On the other hand, despite the lack of a dose/response relationship, the presence of $10 \mu \mathrm{g} / \mathrm{mL}$ PHA increased the rate of formation of antral cavity. This may be associated with increased expression of the $\mathrm{FSH}$ receptors stimulated by PHA at this concentration. Previous in vitro studies have shown that this gonadotropin improves formation of antrum in cultured secondary follicles in caprine (9) and mouse (29) species.

The ultrastructural analysis confirmed the integrity of 


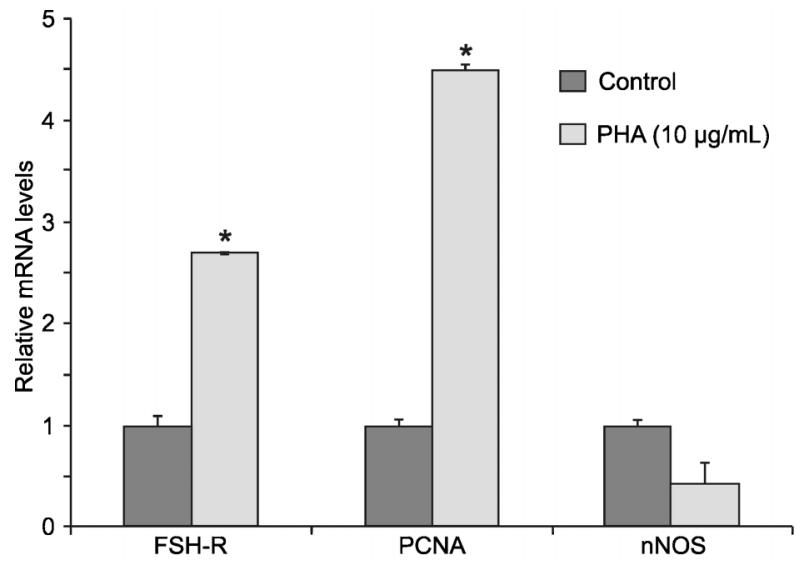

Figure 2. Relative expression of mRNA for FSH-R, PCNA and nNOS in caprine secondary follicles cultured for 6 days with $10 \mu \mathrm{g} /$ $\mathrm{mL}$ PHA. FSH-R = follicle-stimulating hormone receptors; PCNA = proliferating cell nuclear antigen; nNOS $=$ neuronal nitric oxide synthase; $\mathrm{PHA}=$ phytohemagglutinin. Data are reported as means $\pm \mathrm{SD}$. ${ }^{*} \mathrm{P}<0.05$ compared to control (Mann-Whitney U-test).

follicles cultured in medium supplement with $10 \mu \mathrm{g} / \mathrm{mL}$ $\mathrm{PHA}$. Previous dose response studies have shown that high concentrations of PHA $(>80 \mu \mathrm{g} / \mathrm{mL})$ have toxic effects on cultured fibroblasts, while low concentrations $(0.1-10 \mu \mathrm{g} / \mathrm{mL})$ have no positive effects (30). In agreement with these data, the present study has demonstrated that the optimal concentration of PHA to stimulate gene expression and antrum formation in cultured preantral follicles is $10 \mu \mathrm{g} / \mathrm{mL}$. The increased expression of the FSH receptors stimulated by PHA may have contributed to maintain follicular ultrastructure. Previous in vitro studies have shown that FSH kept ultrastructural characteristics of caprine-cultured follicles $(9,28)$. Studies using mice with deficiencies in $\mathrm{FSH}-\mathrm{R}$ expression have allowed further elucidation of the role of FSH in ovarian follicles and it has been reported that mice lacking the FSH-R gene have structural alterations in the ovary (31). Furthermore, there is evidence to suggest that FSH-R deletion results in changes in oocyte structure and function, and disruption of oocyte-granulosa cell communication (32). In addition, PHA facilitates close cell contact by binding to the $\mathrm{N}$-linked carbohydrate core structure (beta 1-6 branching) of glycoproteins on the cell membrane (33). In this study, this lectin may have recognized and mediated adhesion between carbohydrates present in granulosa cells and oocyte, maintaining the follicular ultrastructure. The communication between granulosa cells during the preantral and early antral stages is necessary to ensure subsequent oocyte developmental competence (34). The oocyte is the central regulator of follicular cell functions through the secretion of soluble growth factors such as BMP-15 and GDF-9, which act in the surrounding follicular cells to promote their proliferation and survival (35).

The addition of $10 \mu \mathrm{g} / \mathrm{mL} \mathrm{PHA}$ to the culture medium increased the expression of mRNA for PCNA, indicating an influence of this lectin on granulosa cell proliferation, but a dose/response relationship was not demonstrated. PCNA performs the essential function of providing replicative polymerases with the high processivity required to duplicate the entire genome (36) and has been used as a marker of granulosa cell proliferation in various species $(8,37,38)$. Although lectin PHA has a known role in the mitogenesis of various cell types (1416), the increase in PCNA expression did not reflect an increase in follicular diameter during the culture, probably because of the short culture period. Although extensively studied, the mechanism of stimulation of mitosis by lectins is still not understood. It has been suggested that mitogenic lectins interact with components of cell membranes to stimulate cell proliferation (13).

The present study demonstrates the expression of nNOS in goat ovarian follicles, but no increase in the levels of mRNA for nNOS was observed in response to PHA stimulation during in vitro culture. The nNOS is an enzyme responsible for the synthesis of $\mathrm{NO}$ that was recently demonstrated to be expressed in bubaline granulosa cells and oocytes in different stages of development, indicating its role in the control of follicular growth (24). Nitric oxide can act as a pro- or anti-apoptotic agent in a variety of structures, including ovarian follicles (39). At low concentrations, NO has anti-apoptotic action, but with the increase of its production, it causes DNA damage and induces cell death by apoptosis (39). The role of $\mathrm{NO}$ in regulating ovarian function and reproductive systems has been described by Rosselli et al. (40), who observed correlations between ovarian hormones and $\mathrm{NO}$ production, since an increase in NO is correlated with increased steroidogenesis. Previous studies have shown that PHA can stimulate the production of NO in different cellular types $(22,23)$, but this was not observed in cultured preantral follicles.

Addition of $10 \mu \mathrm{g} / \mathrm{mL}$ PHA during in vitro culture caprine secondary follicles stimulates antrum formation, increases the expression of FSH-R and PCNA, and helps to keep ultrastructural integrity of cultured follicles. These data may be useful for the development of an efficient culture system to promote oocyte growth and maturation in vitro.

\section{Acknowledgments}

Research supported by CNPq (\#562686/2010-0 and \#501221/2009-3) and Fundação Cearense de Apoio ao Desenvolvimento Científico e Tecnológico (FUNCAP, \#PRN-0040-00053.01.00/10). J.R.V. Silva and R.P. Santos are investigators of CNPq. 


\section{References}

1. Roy SK, Treacy BJ. Isolation and long-term culture of human preantral follicles. Fertil Steril 1993; 59: 783-790.

2. Gutierrez CG, Ralph JH, Telfer EE, Wilmut I, Webb R. Growth and antrum formation of bovine preantral follicles in long-term culture in vitro. Biol Reprod 2000; 62: 1322-1328, doi: 10.1095/biolreprod62.5.1322.

3. Serafim MK, Araújo VR, Silva GM, Duarte AB, Almeida AP, Chaves RN, et al. Canine preantral follicles cultured with various concentrations of follicle-stimulating hormone (FSH). Theriogenology 2010; 74: 749-755, doi: 10.1016/ j.theriogenology.2010.03.028.

4. Wu J, Tian Q. Role of follicle stimulating hormone and epidermal growth factor in the development of porcine preantral follicle in vitro. Zygote 2007; 15: 233-240, doi: 10.1017/S0967199407004194.

5. Gupta PS, Ramesh HS, Manjunatha BM, Nandi S, Ravindra JP. Production of buffalo embryos using oocytes from in vitro grown preantral follicles. Zygote 2008; 16: 57-63, doi: 10.1017/S096719940700442X.

6. Arunakumari G, Shanmugasundaram N, Rao VH. Development of morulae from the oocytes of cultured sheep preantral follicles. Theriogenology 2010; 74: 884-894, doi: 10.1016/j.theriogenology.2010.04.013.

7. Saraiva MV, Celestino JJ, Araujo VR, Chaves RN, Almeida $\mathrm{AP}$, Lima-Verde IB, et al. Expression of follicle-stimulating hormone receptor (FSHR) in goat ovarian follicles and the impact of sequential culture medium on in vitro development of caprine preantral follicles. Zygote 2011; 19: 205-214, doi: 10.1017/S0967199410000511.

8. Silva JR, van den Hurk R, Costa SH, Andrade ER, Nunes $A P$, Ferreira FV, et al. Survival and growth of goat primordial follicles after in vitro culture of ovarian cortical slices in media containing coconut water. Anim Reprod Sci 2004; 81: 273-286, doi: 10.1016/j.anireprosci.2003.09.006.

9. Saraiva MV, Rossetto R, Brito IR, Celestino JJ, Silva CM, Faustino LR, et al. Dynamic medium produces caprine embryo from preantral follicles grown in vitro. Reprod Sci 2010; 17: 1135-1143, doi: 10.1177/1933719110379269.

10. Martins FS, Celestino JJ, Saraiva MV, Chaves RN, Rossetto R, Silva $\mathrm{CM}$, et al. Interaction between growth differentiation factor 9 , insulin-like growth factor I and growth hormone on the in vitro development and survival of goat preantral follicles. Braz J Med Biol Res 2010; 43: 728-736, doi: 10.1590/S0100-879X2010007500066.

11. Celestino JJ, Bruno JB, Lima-Verde IB, Matos MH, Saraiva $\mathrm{MV}$, Chaves RN, et al. Steady-state level of kit ligand mRNA in goat ovaries and the role of kit ligand in preantral follicle survival and growth in vitro. Mol Reprod Dev 2010; 77: 231-240.

12. Lis $\mathrm{H}$, Sharon N. Biological properties of lectins. In: Anonymous, The lectins: properties, functions and applications in biology and medicine. London: Academic Press; 1986. p 265-285.

13. Nowell PC. Phytohemagglutinin: an initiator of mitosis in cultures of normal human leukocytes. Cancer Res 1960; 20: 462-466.

14. Sheng Y, Pero RW, Wagner H. Treatment of chemotherapy-induced leukopenia in a rat model with aqueous extract from Uncaria tomentosa. Phytomedicine 2000; 7: 137-143, doi: 10.1016/S0944-7113(00)80086-0.

15. Sell AM, Costa CP. PHA: a lectin that enhanced wound healing in the skin rats. Proceedings of the International Meeting on Vaccines. Salvador: 1998. p 124.

16. Myers RL. Immunology - a laboractory manual. Dubuque: WCB Publishers; 1995.

17. Fagbohun CF, Downs SM. Maturation of the mouse oocytecumulus cell complex: stimulation by lectins. Biol Reprod 1990; 42: 413-423, doi: 10.1095/biolreprod42.3.413.

18. Wang S, Panter KE, Evans RC, Bunch TD. The effects of pokeweed mitogen (PWM) and phytohemagglutinin (PHA) on bovine oocyte maturation and embryo development in vitro. Anim Reprod Sci 2001; 67: 215-220, doi: 10.1016/ S0378-4320(01)00122-1.

19. Tesarik J, Nagy ZP, Mendoza C, Greco E. Chemically and mechanically induced membrane fusion: non-activating methods for nuclear transfer in mature human oocytes. Hum Reprod 2000; 15: 1149-1154, doi: 10.1093/humrep/ 15.5.1149.

20. Kesherwani $\vee$, Sodhi A. Differential activation of macrophages in vitro by lectin concanavalin A, phytohemagglutinin and wheat germ agglutinin: production and regulation of nitric oxide. Nitric Oxide 2007; 16: 294-305, doi: 10.1016/ j.niox.2006.11.001.

21. Kim D, Yamasaki $Y$, Jiang $Z$, Nakayama $Y$, Yamanishi $T$, Yamaguchi $\mathrm{K}$, et al. Comparative study on modeccin- and phytohemagglutinin (PHA)-induced secretion of cytokines and nitric oxide (NO) in RAW264.7 cells. Acta Biochim Biophys Sin 2011; 43: 52-60, doi: 10.1093/abbs/gmq105.

22. Dubey PK, Tripathi $V$, Singh RP, Saikumar G, Nath A, Pratheesh, et al. Expression of nitric oxide synthase isoforms in different stages of buffalo (Bubalus bubalis) ovarian follicles: effect of nitric oxide on in vitro development of preantral follicle. Theriogenology 2012; 77: 280-291, doi: 10.1016/j.theriogenology.2011.08.002.

23. Thaler CD, Epel D. Nitric oxide in oocyte maturation, ovulation, fertilization, cleavage and implantation: a little dab'll do ya. Curr Pharm Des 2003; 9: 399-409, doi: 10.2174/1381612033391748.

24. Huanmin Z, Yong Z. In vitro development of caprine ovarian preantral follicles. Theriogenology 2000; 54: 641-650, doi: 10.1016/S0093-691X(00)00379-4.

25. Livak KJ, Schmittgen TD. Analysis of relative gene expression data using real-time quantitative PCR and the $-2 \Delta \Delta$ CT method. Methods 2001; 25: 402-408, doi: 10.1006/ meth.2001.1262.

26. Rossetto R, Saraiva MV, Dos Santos RR, da Silva CM, Faustino LR, Chaves RN, et al. Effect of medium composition on the in vitro culture of bovine pre-antral follicles: morphology and viability do not guarantee functionality. Zygote 2012; 2: 1-4, doi: 10.1017/S0967199412000044.

27. Markstrom E, Svensson EC, Shao R, Svanberg B, Billig H. Survival factors regulating ovarian apoptosis - dependence on follicle differentiation. Reproduction 2002; 123: 23-30, doi: 10.1530/rep.0.1230023.

28. Matos MH, Lima-Verde IB, Luque MC, Maia JE Jr, Silva JR, Celestino JJ, et al. Essential role of follicle stimulating hormone in the maintenance of caprine preantral follicle viability in vitro. Zygote 2007; 15: 173-182, doi: 10.1017/ 
S0967199407004169.

29. Cortvrindt $\mathrm{R}$, Hu $\mathrm{Y}$, Smitz J. Recombinant luteinizing hormone as a survival and differentiation factor increases oocyte maturation in recombinant follicle stimulating hormone-supplemented mouse preantral follicle culture. Hum Reprod 1998; 13: 1292-1302, doi: 10.1093/humrep/ 13.5.1292.

30. Sell AM, Costa CP. Effects of plant lectins on in vitro fibroblast proliferation. Braz Arch Biol Technol 2003; 46: 349-454, doi: 10.1590/S1516-89132003000300006.

31. Balla A, Danilovich N, Yang Y, Sairam MR. Dynamics of ovarian development in the FORKO immature mouse: structural and functional implications for ovarian reserve. Biol Reprod 2003; 69: 1281-1293, doi: 10.1095/biolreprod.103.015552.

32. Yang Y, Balla A, Danilovich N, Sairam MR. Developmental and molecular aberrations associated with deterioration of oogenesis during complete or partial follicle-stimulating hormone receptor deficiency in mice. Biol Reprod 2003; 69: 1294-1302, doi: 10.1095/biolreprod.103.015610.

33. Sharma V, Surolia A. Analyses of carbohydrate recognition by legume lectins: size of the combining site loops and their primary specificity. $J \mathrm{Mol}$ Biol 1997; 267: 433-445, doi: 10.1006/jmbi.1996.0863.

34. Albertini DF, Combelles CM, Benecchi E, Carabatsos MJ. Cellular basis for paracrine regulation of ovarian follicle development. Reproduction 2001; 121: 647-653, doi: 10.1530/rep.0.1210647.

35. Gilchrist RB, Ritter LJ, Armstrong DT. Oocyte-somatic cell interactions during follicle development in mammals. Anim Reprod Sci 2004; 82-83: 431-446, doi: 10.1016/j.anireprosci.2004.05.017.

36. Maga G, Hubscher U. Proliferating cell nuclear antigen (PCNA): a dancer with many partners. J Cell Sci 2003; 116: 3051-3060, doi: 10.1242/jcs.00653.

37. Wandji SA, Srsen V, Voss AK, Eppig JJ, Fortune JE. Initiation in vitro of growth of bovine primordial follicles. Biol Reprod 1996; 55: 942-948, doi: 10.1095/biolreprod55.5.942.

38. Muskhelishvili L, Wingard SK, Latendresse JR. Proliferating cell nuclear antigen - a marker for ovarian follicle counts. Toxicol Pathol 2005; 33: 365-368, doi: 10.1080/ 01926230590930164

39. Goud AP, Goud PT, Diamond MP, Gonik B, Abu-Soud HM. Reactive oxygen species and oocyte aging: role of superoxide, hydrogen peroxide, and hypochlorous acid. Free Radic Biol Med 2008; 44: 1295-1304, doi: 10.1016/j.freeradbiomed.2007.11.014.

40. Rosselli M, Keller PJ, Dubey RK. Role of nitric oxide in the biology, physiology and pathophysiology of reproduction. Hum Reprod Update 1998; 4: 3-24, doi: 10.1093/humupd/ 4.1.3. 